Sá Motta, Rordigo Patto (2020) On Guard Against the Red Menace: Anti-Communism in Brazil, 1917-1964 (Portuguese-Speaking World: Its History, Politics and Culture). Sussex Academic Press: Brighton, 315 pp. (ISBN-10: 1789760003). Hardcover.

\title{
Katerina Hatzikidi
}

Rodrigo Patto Sá Motta's On Guard Against the Red Menace: Anti-Communism in Brazil explores the centrality of anti-communism in Brazilian political life between 1917 and 1964. Through a masterfully rich analysis, the book diligently knits together landmark moments while highlighting the 'residual' nature of the anti-communist imaginary throughout $20^{\text {th }}$ century Brazilian history. The book sheds light on the structural nature of anti-communism and the ways in which it has shaped important political developments in the country. Its publication in English, based on the 2002 Portuguese version with a new afterword, is a much-welcomed contribution to studies on contemporary Brazil. Nearly twenty years after its original publication, its reading remains highly relevant and key to understanding the lasting influence of anti-communism on Brazilian political discourse.

On Guard Against the Red Menace underscores the importance of unpacking anti-communism to understand not just Brazilian politics but also world events of the past century. An important element here is the heterogeneity that characterises the anti-communist front, formed around a negative agenda and gathering diverse actors and projects. Uniting against what is perceived as a common enemy, such movements gain traction at certain historical moments, when the 'communist menace' is perceived as most threatening to the established status quo. Anti-communism then results 'from an intricate mixture of opportunistic manipulation and conviction, which combined in different ways and intensity over the course of history' (5).

While the analysis culminates with the examination of the two main anti-communist waves, centred around the 1937 and 1964 coup d'états, the early years of anti-communist fear, in the aftermath of the Russian Revolution, are explored in the first chapter. Particular emphasis is drawn here on the foreign influence of anti-communist representations, especially from the United States (10). The following four chapters dissect Brazilian anticommunism uncovering its ideological foundations, as well as its organisational and operational aspects, before going on to analyse how these elements interacted with and profoundly influenced national politics, in chapters seven and eight.

Patto Sá Motta identifies three main matrices of anti-communist representations in Brazil, namely: Christianity, nationalism, and liberalism. These matrices are closely linked, though not exclusively, to the Catholic church, the armed forces, and the business world, respectively. Segments of the abovementioned institutions saw communism and, very often, progressive leftist politics in

B RASILIANA: Journal for Brazilian Studies. Vol. 10, No. 2, 2021. ISSN 2245-4373. 
general, as a threat to notions of freedom, hierarchy, and order that informed the very foundations and values around which such institutions are structured. For such reactionary segments, 'democracy' became the antonym of 'communism' and they professed their love for this empty signifier in an effort to align themselves to the "free, Western and Christian world" (43). Of the three main institutions that represented the three matrices, the armed forces and the Catholic church had, according to Patto Sá Motta, a leading role in anti-communist mobilisation, though and it was ultimately the Catholic church that "had the best instruments to combat the 'red menace"' (46).

Chapter three delves into "the anti-communist imaginary", where demons, pathological metaphors (especially those alluding to an infiltration of the healthy social organism in order to debilitate it from within), moral panic, and images of the 'Soviet inferno' gain centre stage. An important element that informs the anti-communist imaginary is the conviction that communism is an intrinsically alien idea implanted from outside and essentially "irreconcilable with the traditions of the Brazilian character and soul" (36). Hence, communism is essentially a foreign menace and the result of a conspiracy that forms part of Soviet imperialism (especially in the early years of anticommunism) or, later, of a global communist conspiracy (involving China and, closer to home, Cuba). This foreign menace wants to "destroy order, tradition and Christian society" (48). This is part of the reason why, for example, the armed uprising of 1935, known as Intentona Comunista, was generally treated as "equivalent to an external attack on the country" (38).

In the 1930s, when the first big anti-communist wave shook Brazilian society, anticommunism embraced anti-Semitism, often conflating Jews and communists as two sides of the same coin. The 'Judeo-Bolshevik' threat was most emblematically manifested by the 'Cohen Plan': an alleged complot about a communist revolution in Brazil. The Cohen Plan, which, it is worth mentioning, was entirely fabricated and written by members of the armed forces, encapsulated fears and conspiracy theories circulating at the time. Its 'discovery' acted as a catalyst for the 1937 coup d'état and justified new migration policies restricting the entry of Jewish people in Brazil (59).

In chapter four, dedicated to 'the anti-communist iconography', Patto Sá Motta draws on Erwin Panofsky's 'iconological interpretation' to critically discuss some of the iconography influenced by anti-Communism that circulated in Brazil (84). This visual analysis provided strengthens and complements the discussion in the previous chapter. Chapter five is dedicated to 'anti-communist organisations'; Brazilian entities created to combat communism (109). This discussion is particularly relevant to the second anti-communist wave, since in the 1930s the number of such entities was markedly smaller. The author does an impressive job of recovering registers of the names and activities of several important organisations dedicated to creating and spreading anticommunist propaganda, despite the scarcity and ephemeral nature of archival records (112). Chapter six focuses on 'the anti-communist industry', that is, to "the opportunistic exploitation of the 'red menace'" and to "those manipulators who took advantage of the fear of communism" (144). 
Making use of 'profitable ghosts' to deliberately distort reality or create overblown narratives of fear to serve their mostly political purposes, anti-communist industrialists aimed to use "anticommunism to justify authoritarian interventions in national political life" (145).

The final two chapters are dedicated to the two major anti-communist waves, namely 19341937 (chapter seven) and 1961-1964 (chapter eight), both of which ended with coup d'états that would promise to restore order and save the country from the communist peril. One of the book's greatest strengths is the author's ability to weave together disparate political events and historical moments to highlight important continuities, while also acknowledging disruptions and changes. For example, while anti-Semitism remained rather marginal after the 1930s, the association of communism with evil and disorder, as well as the active role of mainstream press in influencing political events (188), continued to be relevant. In addition, the association of communism with corruption and moral degradation (189), which was consolidated during the first wave (1935-1937), not only resurfaced during the second major wave (1961-1964) but made a forceful comeback during the most recent political upheaval in the country (2013-2018). As did, for many, the notion that the armed forces are "the nation's only sane and honest force" (197). Indeed, it is impossible to read On Guard Against the Red Menace in 2021 and not be tempted to make comparisons between the anticommunist imaginary analysed in the book and the discourse of Jair Bolsonaro. One might even wonder whether Brazil is going through a third major wave.

This meticulous and well-balanced work on the history of anti-communism in Brazil focuses mainly on the states of Rio de Janeiro, Minas Gerais, and São Paulo. While spatial limitations are justified and accounted for (an in-depth research will inevitably narrow its focus to better explore the available archival work and these three states play an important role in national politics), it would be interesting to gain insights into the ways anti-communism played out in other corners of the country. This could be the goal of a future project. In Chapter eight, a brief contextualisation of how Vargas went from authoritarian philo-fascist leader, as described in earlier chapters, to being seen as the enemy par-excellence of the ruling classes (208) might have helped readers better situate the analysis.

Overall, this is an essential read for anyone interested in the roots and manifestations of anticommunism in Brazil throughout the $20^{\text {th }}$ century, and in understanding both its recurring and longlasting nature. Patto Sá Motta's historical analysis compellingly shows how anti-communism is a deep-seated, structural phenomenon in Brazil, a product of national and international political conjunctures, that evolves and takes new shapes but never entirely disappears. Finally, this book on anti-communism is an important step towards filling a research lacuna. As the author himself identifies, while much have been written about communism, anti-communism has remained surprisingly under-researched. Written in an easy flowing yet rich style, this is an exceptional book that will captivate and enlighten its readers. 